\title{
Knowledge and Acceptance of Labour Analgesia in Pregnant Women
}

\author{
Mona Sharma, ${ }^{1}$ Saurya Dhungel, ${ }^{2}$ Sujata Niroula, ${ }^{1}$ Manan Karki, ${ }^{1}$ \\ ${ }^{1}$ Department of Anaesthesia and Intensive Care, Kathmandu Medical College, Sinamangal, Kathmandu, \\ Nepal. ${ }^{2}$ Deaprtment of Public Health, Tribhuvan University, Kathmandu, Nepal.
}

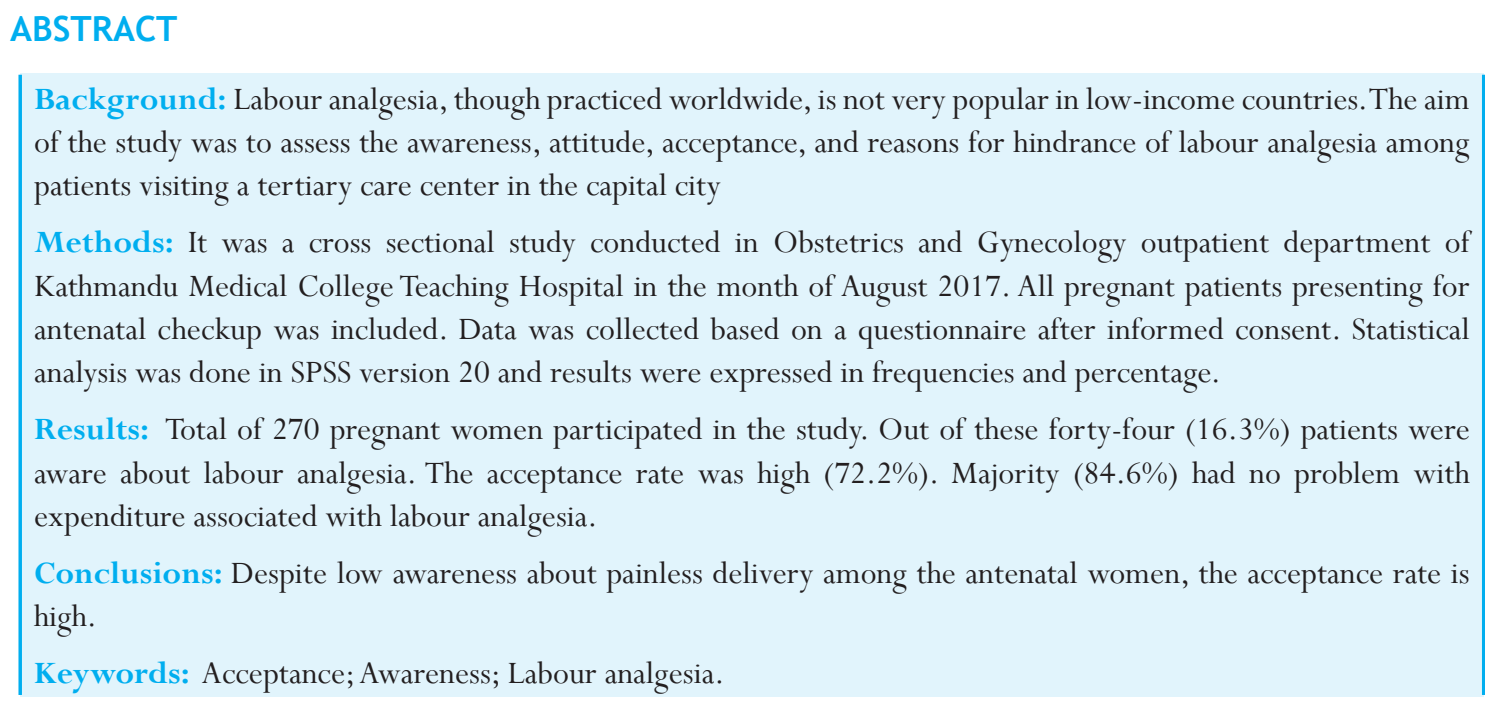

\section{INTRODUCTION}

Labor pain is one of the major determinants of women's childbirth experience. Epidural labour analgesia is the gold standard method, ${ }^{1,2}$ with no evidence of harm to the neonate ${ }^{3,4}$ but, beneficial effect has been observed. ${ }^{5,6}$

Developed countries have high acceptance rate of labour analgesia, ${ }^{7}$ therefore, their data focuses on overall birth experience. ${ }^{8}$ In our country, little information has been documented on the views of pregnant women about the use of analgesia in labour. The very fact that, childbirth can be achieved without pain may seem absurd to many. ${ }^{9}$ Culture, upbringing and ethnicity can influence the attitude towards pain. ${ }^{10}$ Maternal request for pain relief suffices the indication for labour analgesia according to American Society of Anaesthesiologists. ${ }^{11}$ Women who received labour analgesia were higly satisfied with experience of childbirth. ${ }^{12}$ This survey, assessed the awareness and acceptance about labour analgesia among antenatal women and attempted to point out the reasons for impediment for not receiving analgesia.

\section{METHODS}

Following institutional ethical committee approval, on August 2017 a cross sectional study was carried out in antenatal clinic of Kathmandu medical college teaching hospital. Sample size of 270 patients was calculated based on a previous study ${ }^{10}$ where only $27 \%$ of the patients were aware about labour analgesia and using the formula $4 \mathrm{pq} / \mathrm{d} 2$. Where $\mathrm{p}$ is proportion of aware patients $(27 \%)$, $q$ is $100-p$ and $d$ is absolute precision or alpha error of $5 \%$.

Astructured questionnaire was used to obtain information about the personal data and other clinical and nonclinical data about the patient. The questionnaire was prepared after discussion among the authors and referring to previous studies. ${ }^{9},{ }^{10} \mathrm{~A}$ pilot study was done on 20 patients attending the antenatal clinic, and the questionnaire justified our aim, hence validated. To reduce the subject bias, we assured the participants that we respected their views and beliefs. We would keep the data confidential and complete anonymity would be provided. There were no leading questions. Patients were included only after an informed consent was obtained. The investigator inquired patients based on the questionnaire, in local language. If any patient regarded the questions non-answerable or lost interest in the survey, those patients were excluded from the study. Single interviewer collected the data, who had
DOI: http://dx.doi.org/10.3126/

jnhrc.v16i3.21428
Correspondence: Mona Sharma, Department of Anaesthesiology and Intensive Care, Kathmandu Medical College, Sinamangal, Kathmandu, Nepal. Email: dr.sharmamona@gmail.com, Phone: +9779843580393. 
Knowledge and Acceptance of Labour Analgesia in Pregnant Women

previous experiences with community surveys. To avoid interviewer's bias, he recorded the answers as provided by the respondent. He provided neutral explanations and feedbacks.

The survey had two sections. The first section, demographic data was recorded, such as age, education level, occupation, parity, and previous normal or cesarean delivery. The second section consisted of main objective of the study; comprising of questions to assess the knowledge and perception about labour analgesia. Patients were asked about the pain they expected to occur in the present pregnancy. In case of multigravida, we also inquired about their previous experience. However, if the patient had little or no knowledge about painless labour; we educated patients regarding the types of analgesia focusing on labour epidural analgesia. After imparting the facts and myths; patients were asked if they would prefer labour analgesia during the present pregnancy. If patients were reluctant we inquired the reason for hindrance.

The data obtained were analyzed using the computer software program, Statistical Package for Social Sciences version 20, (SPSS Incorporation) and the results were displayed on tables in numbers and percentages. Pearson Chi-Square test was used to obtain correlation between different factors.

\section{RESULTS}

Two hundred seventy pregnant females were approached, and all of them actively participated in the survey. Therefore, none were excluded. The mean age of the participants was 25.9. The influence of sociodemographic profile on awareness of painless deliveryis demonstrated below (Table 1).

\begin{tabular}{|c|c|c|c|c|}
\hline Characteristics & & $\begin{array}{r}\text { Number } \\
(\%)\end{array}$ & $X^{2}$ & $\begin{array}{r}P \\
\text { value }\end{array}$ \\
\hline \multirow{4}{*}{ Education } & Uneducated & $9(3.3)$ & \multirow{4}{*}{13.9} & \multirow{4}{*}{$0.003^{*}$} \\
\hline & $\begin{array}{l}\text { Could read } \\
\text { and write }\end{array}$ & $\begin{array}{r}36 \\
(13.3)\end{array}$ & & \\
\hline & $\begin{array}{l}\text { Intermediate } \\
\text { level }\end{array}$ & $\begin{array}{r}130 \\
(48.1)\end{array}$ & & \\
\hline & $\begin{array}{l}\text { Graduate and } \\
\text { above }\end{array}$ & $\begin{array}{r}95 \\
(35.2)\end{array}$ & & \\
\hline \multirow{2}{*}{ Residence } & Kathmandu & $\begin{array}{r}240 \\
(88.9)\end{array}$ & \multirow{2}{*}{0.49} & \multirow{2}{*}{0.78} \\
\hline & $\begin{array}{l}\text { Outskirts of } \\
\text { Kathmandu }\end{array}$ & $\begin{array}{r}30 \\
(11.1)\end{array}$ & & \\
\hline
\end{tabular}

\begin{tabular}{|c|c|c|c|c|}
\hline \multirow{4}{*}{ Occupation } & $\begin{array}{l}\text { Self } \\
\text { employed } \\
\text { (Shopkeeper, } \\
\text { beauty parlor } \\
\text { etc.) }\end{array}$ & $35(13)$ & \multirow{4}{*}{11.01} & \multirow{4}{*}{0.12} \\
\hline & Housewife & $\begin{array}{r}173 \\
(64.1)\end{array}$ & & \\
\hline & $\begin{array}{l}\text { Skilled job } \\
\text { (teacher, } \\
\text { nurse) }\end{array}$ & $\begin{array}{r}37 \\
(13.7)\end{array}$ & & \\
\hline & $\begin{array}{l}\text { Service/ } \\
\text { clerical }\end{array}$ & $25(9.3)$ & & \\
\hline
\end{tabular}

Data given in number (percentage), chi square, * $\mathrm{P}$ value $<0.05$ staitistically significant.

Total awareness amongst all of the participants and among them who had knowledge about labour analgesia, their source of information is depicted in the bar diagram (Chart 1).

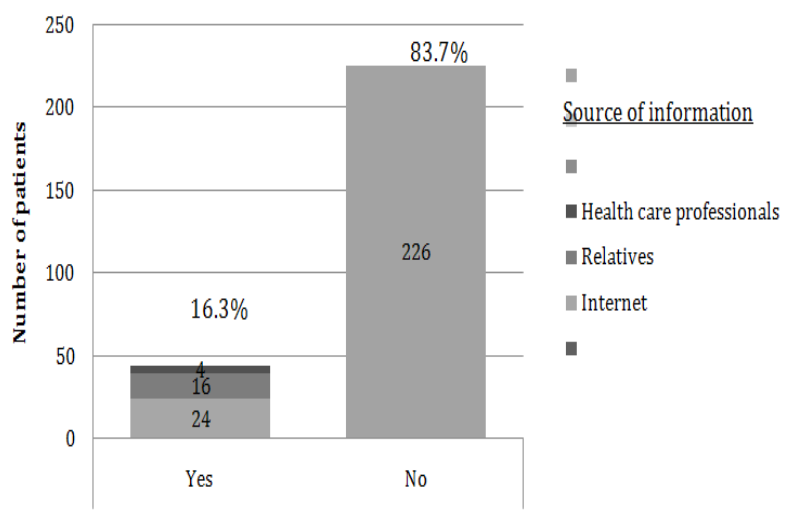

Figure 1. Knowledge and source of information about labour analgesia.

Among the forty four (16.3\%) patients, only three (1.11\%) had complete knowledge about painless delivery, rest had only some idea about it.Experience of past labour and delivery in multigravida women is shown in Table 2. Table 2. Experience of multigravida regarding analgesia during previous labour and delivery.

\begin{tabular}{llr}
\hline Characteristics & Response & Number (\%) \\
\hline $\begin{array}{l}\text { Demand for } \\
\text { analgesics }(\mathrm{n}=121)\end{array}$ & Yes & $32(32.2)$ \\
& No & $12(30.8)$ \\
$\begin{array}{l}\text { Type of analgesia } \\
\text { received }(\mathrm{n}=39)\end{array}$ & Assurance & $15(38.5)$ \\
\hline & $\begin{array}{l}\text { Injections } \\
\text { Did not receive }\end{array}$ & $12(30.8)$ \\
\hline $\begin{array}{l}\text { Reason for not } \\
\text { demanding } \\
\text { analgesic }(\mathrm{n}=82)\end{array}$ & Not aware & $32(39)$ \\
\hline & Natural process & $42(51.2)$
\end{tabular}




Could be harmful $\quad 8(9.8)$
for baby

Data expressed in numbers and percentage.

The influence of experience of previous childbirth experience was assessed and shown in table 3.

Table 3. Impact of previous childbirth experience on the acceptance of labour analgesia.

Number

(\%)

\begin{tabular}{|c|c|c|c|c|}
\hline \multirow{4}{*}{$\begin{array}{l}\text { Previous } \\
\text { mode of } \\
\text { delivery }\end{array}$} & $\begin{array}{l}\text { Home } \\
\text { delivery }\end{array}$ & $22(18.2)$ & \multirow{4}{*}{4.33} & \multirow{4}{*}{0.631} \\
\hline & $\begin{array}{l}\text { VD without } \\
\text { labour } \\
\text { analgesia }\end{array}$ & $63(52.1)$ & & \\
\hline & $\begin{array}{l}\text { Emergency } \\
\text { LSCS }\end{array}$ & 31 (25.6) & & \\
\hline & $\begin{array}{l}\text { Elective } \\
\text { LSCS }\end{array}$ & $5(4.1)$ & & \\
\hline \multirow{4}{*}{$\begin{array}{l}\text { Time } \\
\text { required } \\
\text { for last } \\
\text { delivery }\end{array}$} & $<4$ hours & $33(27.3)$ & \multirow{4}{*}{3.20} & \multirow{4}{*}{0.783} \\
\hline & 4-12 hours & $30(24.8)$ & & \\
\hline & $12-24$ hours & $27(22.3)$ & & \\
\hline & $>24$ hours & $31(25.6)$ & & \\
\hline \multirow{3}{*}{$\begin{array}{l}\text { Intensity } \\
\text { of pain }\end{array}$} & Mild & $14(11.6)$ & \multirow{3}{*}{8.42} & \multirow{3}{*}{0.20} \\
\hline & Moderate & 23 (19) & & \\
\hline & Severe & $84(69.4)$ & & \\
\hline
\end{tabular}

Data expressed in number and percentage, $\mathrm{X}^{2}$ chi square, $P$ value $<0.05$ was considered statistically significant, LSCS lower segment cesarean section, VD vaginal delivery.

Out of 270 patients, 195 (72.2\%) accepted labour analgesia and there was no correlation between acceptance and socio-demographic profile or past experience in case of multigravida. The rationale for not accepting pain relief during childbirth and effect of expenditure on the decision is given in Table 4.

Table 4. Reason for not accepting pain relief during childbirth and impact of cost on the decision.

\begin{tabular}{|c|c|c|}
\hline Characteristics & & Number (\%) \\
\hline \multirow{4}{*}{$\begin{array}{l}\text { Reason for } \\
\text { hindrance }(n=75)\end{array}$} & Natural process & $35(46.7)$ \\
\hline & Could harm the baby & $17(22.7)$ \\
\hline & $\begin{array}{l}\text { If only obstetrician } \\
\text { had advised }\end{array}$ & $14(18.7)$ \\
\hline & Fear of LSCS & $9(12)$ \\
\hline \multirow{2}{*}{$\begin{array}{l}\text { Ready to expend } \\
(n=195)\end{array}$} & Yes & $165(84.6)$ \\
\hline & No & $30(15.4)$ \\
\hline \multirow{2}{*}{$\begin{array}{l}\text { Consider if the } \\
\text { service is free } \\
(n=30)\end{array}$} & Yes & $25(83.3)$ \\
\hline & No & 5 \\
\hline
\end{tabular}

Data represented in number and percentage. LSCS lower segment Cesarean section.

Perspective of patients towards upcoming labour and delivery is given in table 5 .

\begin{tabular}{|c|c|c|}
\hline \multirow{5}{*}{$\begin{array}{l}\text { Emotion towards } \\
\text { labour }\end{array}$} & & Number (\%) \\
\hline & Calm & $118(44)$ \\
\hline & Little anxious & $16(6)$ \\
\hline & $\begin{array}{l}\text { Concerned about } \\
\text { the baby }\end{array}$ & $75(28)$ \\
\hline & Fear of the pain & $61(22)$ \\
\hline \multirow[t]{3}{*}{ Anticipated pain } & Mild & $8(3)$ \\
\hline & Moderate & $57(21.1)$ \\
\hline & Severe & 205 (75.9) \\
\hline
\end{tabular}

Data expressed in numbers and percentage.

\section{DISCUSSION}

In developing countries, pain, associated with childbirth, is often considered natural. And the idea of abolishing it with medicines seems unnecessary or against the traditional values. Knowledge about labour analgesia was present in $16.3 \%$ of our pregnant women, this value is lesser than studies performed earlier by Olayemi et al, ${ }^{10}$ but more than Nabukenya et $\mathrm{al}^{13}$ and Naithani et al. ${ }^{14}$ However, it is very low in comparison to data from the developed countries, where awareness rate is about $80 \% .{ }^{15,16}$ This suggests that people need to be enlightened about such service available in a tertiary care hospital. The data from various low income or third world countries, is almost the same, India $(10.2 \%)^{9}$ Nigeria $(27 \%)^{10}(19.5 \%)^{17}$ Uganda $(7 \%) .{ }^{13}$ This image states the practice of labour analgesia is not mandated and not rendered important by practioners. Among the patients who knew about painless labour, most had gathered the information from the Internet and media. Our data is in contrary to other literatures, which quote that health care professionals and previous experience or friends and family are the source of information for patients. ${ }^{13,18,19} \mathrm{It}$ seems not illogical to note that health care professional do not include educating women about painless deliver during antenatal visits.

Neither significant association between past experiences of labour with awareness nor acceptance of labour analgesia was observed amongst multigravida.Patients, who had asked for pain relief during previous labour, received intramuscular injection of analgesic drug. Though not mentioned in the questionnaire we had inquired if they were happy with the analgesic technique that they received. None of them had an affirmative answer. While there has been positive reinforcement 
after receiving labour epidural analgesia. ${ }^{20}$

In our study population, only nine (3.3\%) were illiterate; and majority were housewives (64.1\%) and resident of Kathmandu city (88.9\%). Although, the aware population percentage was small (16.3\%), patients desiring painless labour were high(72.2\%). This means that if given choice, parturients want to experience painless childbirth. Our acceptance rate is higher than other studies. ${ }^{10}$ Previous use and knowledge of epidural analgesia were significant factors for acceptance of labour analgesia in another study. ${ }^{17} \mathrm{~A}$ study proved statistically significant association between socioeconomic status, gravida, pain perspective and awareness of labour analgesia. ${ }^{9}$ Our study population had no such factors that influenced acceptance or awareness about labour analgesia except for education, which had significant association with awareness. Patients who had education qualification above graduation were knowledgeable about painless delivery and this could be because of their broadened point of view and wanting a better quality of medical management for their childbirth.

Two hundred and five patients (75.9\%) both primigravida and multigravida; anticipated that the pain would be severe in upcoming labour. This in accordance with findings of Melzack et al, ${ }^{21}$ whose $80 \%$ study population consisting of both primi and multigravida experienced excruciating pain. However, in a study by Oladokun et al, ${ }^{17}$ the pain score differed significantly with parity, where $41 \%$ nulliparous rated labour pain to be mild and $50.4 \%$ multiparous women rated it to be severe. Many rspondents(43.7\%) admitted to be calm and only sixtyone $(22.6 \%)$ of them were concerned about the pain. But on giving them a choice of pain relief during labour, $72.2 \%$ patients desired for labour analgesia. This indicates that many mothers want the labour and delivery to be pain free.

On inquiring if they were ready to listen to information about painless delivery; majority, 241 (89.3\%) were interested. This implies that patients are ready to hear about new information, provided physician take an extra step forward. Authors believe that antenatal visits are the best time to impart the information. This is backed up by a study, which states the information provided about pain relief during antenatal periods are the most useful. ${ }^{22}$

Among the patients who declined labour epidural analgesia, $46.7 \%$ described their hindrance to acceptability was that childbirth was natural; which was an expected answer in studies conducted in low income countries. ${ }^{9}$ Even in the Nigerian study, the $76.5 \%$ of patients who had refused, had the same reason. ${ }^{10}$
Society like ours has beliefs that are encrypted in peoples' mind and cultural practice, which plays role in making a decision. This is a fact that some patients do not regard pain as a cause of maternal dissatisfaction during labour. ${ }^{23}$ Fourteen (18.7\%) expressed that if their primary doctor that is the obstetrician had advised, they would have then considered it. Patients come to antenatal clinics and develop a bond with the primary doctor. Therefore, it would be very much effective if our obstetricians, nurses were encouraged to talk to the patients about painless labour. There are literatures citing that information provided by healthcare professionals are desired by patients and are effective as well. ${ }^{18,19}$ Being a low-income country expenditure on labour analgesia could have been a factor for hindrance among respondents, but surprisingly, one sixty five (85.93\%) have accepted the extra cost.

Fear of labour pain has resulted in escalation of elective cesarean section, as evidenced by a study. ${ }^{24}$ The unawareness among women about labour analgesia should be combated with information, which should be freely available in form of pamphlets or posters in the antenatal clinic. They should be given the information in the antenatal period. Should they have any queries, they should have an access to the physician providing such service to avoid misconceptions and facilitate the knowledge. ${ }^{13,17,19}$

Limitations of our study could be the fact that, this was a structured questionnaire; respondents could have felt that the questions were mechanistic and could distort what they really meant or have experienced. Multigravida could have recall bias about previous experience about labour and childbirth. And the study was based in a single centre.Further surveys in various regions of the country could investigate this desire

\section{CONCLUSIONS}

Despite the fact that very few women had knowledge about labour analgesia, majorities were enthusiastic to adopt pain relief for their upcoming delivery. Epidural analgesia was not desirable to $27.78 \%$ of women despite apparent knowledge of the technique. Their reasons could be explored in future studies, which might guide the process of introducing an epidural service.

\section{REFERENCES}

1. Rizzo D, Giustiniano E, Cascini V. Epidural analgesia for painless delivery. Our experience. Minerva Anestesiol. 1999;65(10):711-5.[Full Text Link]

2. Borowska A, Szymusik I, Wielgoś M, KrzemieńWiczyńska S. Retrospective assessment of epidural 
analgesia during labor according to parturients. Ginekol Pol. 2005;76(4):277-83. [Full Text Link]

3. Sieńko J, Czajkowski K, Swiatek-Zdzienicka M, Krawczyńska-Wichrzycka R. Epidural analgesia and the course of delivery in term primiparas. Ginekol Pol. 2005;76(10):806-11. [Full Text Link]

4. Decca L, Daldoss C, Fratelli N, Lojacono A, Slompo M, Stegher C, et al. Labor course and delivery in epidural analgesia: a case-control study. J Matern-Fetal Neonatal Med. 2004;16(2):115-8.

5. Lederman RP, Lederman E, Work B, McCann DS. Anxiety and epinephrine in multiparous women in labor: relationship to duration of labor and fetal heart rate pattern. Am J Obstet Gynecol. 1985;153(8):870-7. [Science Direct] [DOI]

6. Levinson G, Shnider SM, DeLorimier AA, Steffenson JL. Effects of maternal hyperventilation on uterine blood flow and fetal oxygenation and acid-base status. Anesthesiology. 1974;40(4):340-7. [Link]

7. Burnstein R, Buckland R, Pickett JA. A survey of epidural analgesia for labour in the United Kingdom. Anaesthesia. 1999;54(7):634-40. [DOI] [Full Text Link]

8. Pandya S. Labour analgesia: Recent advances. Indian J Anaesth. 2010;54(5):400. [PubMed]

9. Poomalar G.K LS. Awareness of labour analgesia among antenatal women in semi urban area. Int J Reprod Contracept Obstet Gynecol. 2016;5(8):2612-7. [DOI]

10. Olayemi O, Aimakhu CO, Udoh ES. Attitudes of patients to obstetric analgesia at the University College Hospital, Ibadan, Nigeria. J Obstet Gynaecol J Inst Obstet Gynaecol. 2003;23(1):38-40.

11. American Society of Anesthesiologists Task Force on Obstetric Anesthesia. Practice guidelines for obstetric anesthesia: an updated report by the American Society of Anesthesiologists Task Force on Obstetric Anesthesia. Anesthesiology. 2007;106(4):843-63.

12. Cambic CR, Wong CA. Labour analgesia and obstetric outcomes. Br J Anaesth. 2010 Dec;105(Supplement 1):i50-60. DOI: $10.1093 / \mathrm{bja} / \mathrm{aeq} 311[\mathrm{DOI}]$

13. Nabukenya MT, Kintu A, Wabule A, Muyingo MT, Kwizera A. Knowledge, attitudes and use of labour analgesia among women at a low-income country antenatal clinic. BMC Anesthesiol. 2015;15(1). [DOI][Full Text Link]

14. Naithani U, Bharwal P. Knowledge, attitude and acceptance of antenatal women toward labor analgesia and caesarean section in a medical college hospital in India. J Obstet Anaesth Crit Care. 2011;1(1):13-20.[Full Text Link]
15. Paech M. "Just put it in!" Consent for epidural analgesia in labour. Anaesth Intensive Care. 2006;34(2):147-9. [Full Text Link]

16. Van Houwe P, Heytens L, Vercruysse P. A survey of obstetric an aesthesia practice in Flanders. Acta Anaesthesiol Belg. 2006;57(1):29-37. [PubMed]

17. Oladokun A, Eyelade O, Morhason-Bello I, Fadare O, Akinyemi J, Adedokun B. Awareness and desirability of labor epidural analgesia: a survey of Nigerian women. Int J Obstet Anesth. 2009;18(1):38-42. [DOI][Science Direct]

18. Ekweani J, Avidime S. The awareness and desirability of pain relief in labour among pregnant women in Zaria. P H Med J. 2016;10(3):115. [Full Text Link]

19. Mugambe J, Nel M, Hiemstra L, Steinberg W. Knowledge of and attitude towards pain relief during labour of women attending the antenatal clinic of Cecilia Makiwane Hospital, South Africa. South Afr Fam Pract. 2007;49(4):16-16d. [DOI][Full Text Link]

20. Leighton BL, Halpern SH. The effects of epidural analgesia on labor, maternal, and neonatal outcomes: a systematic review. Am J Obstet Gynecol. 2002 May;186(5 Suppl Nature):S69-77. [DOI][Science Direct]

21. Melzack R. The myth of painless childbirth (The John J. Bonica Lecture): Pain. 1984;19(4):321-37. [DOI][Science Direct]

22. Swan HD, Borshoff DC. Informed consent--recall of risk information following epidural analgesia in labour. Anaesth Intensive Care. 1994;22(2):139-41. [Link]

23. Hodnett ED, Gates S, Hofmeyr GJ, Sakala C. Continuous support for women during childbirth. In: The Cochrane Collaboration, editor. Cochrane Database of Systematic Reviews. Chichester, UK: John Wiley \& Sons, Ltd; 2012.

24. Aksoy M, Aksoy AN, Dostbil A, Celik MG, Ince I. The Relationship between Fear of Childbirth and Women's Knowledge about Painless Childbirth. Obstet Gynecol Int. 2014;2014:274303. [DOI][Link] 